\title{
Hoyosella altamirensis gen. nov., sp. nov., a new member of the order Actinomycetales isolated from a cave biofilm
}

Correspondence

Verónica Rodríguez-Nava veronica.rodriguez@sante.univlyon 1.fr

\author{
Valme Jurado, ${ }^{1}$ Reiner M. Kroppenstedt, ${ }^{2}$ Cesáreo Saiz-Jimenez, ${ }^{1}$ Hans- \\ Peter Klenk, ${ }^{2}$ Delphine Mouniée, ${ }^{3,4}$ Leonila Laiz, ${ }^{1}$ Andrée Couble, ${ }^{3,4}$ \\ Gabriele Pötter, ${ }^{2}$ Patrick Boiron ${ }^{3,4}$ and Verónica Rodríguez-Nava ${ }^{3,4}$
${ }^{1}$ Instituto de Recursos Naturales y Agrobiología, CSIC, Apartado 1052, E-41080 Sevilla, Spain
${ }^{2}$ Deutsche Sammlung von Mikroorganismen und Zellkulturen, D-38124 Braunschweig, Germany
${ }^{3}$ Université de Lyon and UMR CNRS 5557, Center for Microbial Ecology, Opportunistic Pathogens Bacterial and Environment Research Group, French Observatory for Nocardiosis, Faculté de Pharmacie, Université Lyon I, F-69622 Villeurbanne, France \\ ${ }^{4}$ Ecole Nationale Vétérinaire de Lyon, F-69280 Marcy l'Etoile, France
}

A number of novel bacterial taxa have been isolated from caves and described in recent years. The new genera and species described belong mainly to the suborders Corynebacterineae, Pseudonocardineae and Micrococcineae (Lee et al., 2000, 2001; Lee, 2006a, b; Seo et al., 2007; Jurado et al., 2005a, b; Groth et al., 1999, 2002; Margesin et al., 2004; Schumann et al., 2004). White colonies are widespread in Altamira Cave, Cantabria, Spain, from the entrance as far as the Polychromes Hall, in a transect of less than $100 \mathrm{~m}$. Analysis of this microbial community has revealed that the colonies are formed by a consortium of

The GenBank/EMBL/DDBJ accession number for the 16S rRNA gene sequence of strain OFN S3 $1^{\top}$ is FJ179485.

The cellular fatty acid profile of strain OFN S31 ${ }^{\top}$ is available as supplementary material with the online version of this paper. more than 30 different species, as detected by denaturing gradient gel electrophoresis, many of them uncultured and unidentified (Schabereiter-Gurtner et al., 2002; Gonzalez et al., 2006). Recently, some novel species have been described from these white colonies, such as Aurantimonas altamirensis (Jurado et al., 2006) and Nocardia altamirensis (Jurado et al., 2008). In this work, a polyphasic approach was used to determine the taxonomic position of bacterial strain OFN S31 ${ }^{\mathrm{T}}$. This strain was collected as a member of the complex microbial community that produces the white colonies, isolated or in masses of hundreds on the cave ceiling and walls.

Strain OFN S31 ${ }^{\mathrm{T}}$ was isolated on starch-casein agar at $28{ }^{\circ} \mathrm{C}$ but also grew on brain heart infusion (BHI; Difco), Bennett's agar (Jones, 1949) and trypticase soy agar (TSA; 
MacFaddin, 1985). The growth temperature was tested in the range $10-46{ }^{\circ} \mathrm{C}$. The strain grew on Bennett's agar at $20-37^{\circ} \mathrm{C}$, with optimum growth at $28{ }^{\circ} \mathrm{C}$. The colonies were circular, smooth and cream in colour, with a diameter of 1-2 mm after 3 weeks on Bennett's medium at $28{ }^{\circ} \mathrm{C}$. Tolerance of $\mathrm{NaCl}$ was studied on Bennett's agar supplemented with $0-10 \%(\mathrm{w} / \mathrm{v}) \mathrm{NaCl}$. Growth occurred with $6 \% \mathrm{NaCl}$, although the optimum $\mathrm{NaCl}$ concentration for the growth of strain OFN S31 ${ }^{\mathrm{T}}$ was $2-4 \% \mathrm{NaCl}$. This differs from the phylogenetically and chemotaxonomically closest strains (Table 1). Strain OFN S31 ${ }^{\mathrm{T}}$ was slightly acidalcohol-fast in a modified Ziehl-Neelsen test $(1 \%$ acid decoloration) (Boiron et al., 1993). For determination of cell morphology, samples were fixed in $2.5 \%(\mathrm{w} / \mathrm{v})$ glutaraldehyde (0.1 M cacodylate buffer, $\mathrm{pH}$ 7.2-7.4). After $1 \mathrm{~h}$ of fixation, the cells were washed three times in cacodylate buffer and post-fixed for $1 \mathrm{~h}$ in $1 \%(\mathrm{w} / \mathrm{v})$ osmium tetroxide, dehydrated in a graded ethanol series

Table 1. Physiological characteristics that can be used to differentiate strain OFN S3 $1^{\top}$ from its closest relatives

Strains: 1, strain OFN S31 ${ }^{\mathrm{T}} ; 2$, M. fallax DSM $44179^{\mathrm{T}} ; 3$, C. amycolatum DSM 6922 $2^{\mathrm{T}}$; 4, C. kroppenstedtii DSM 44385 ${ }^{\mathrm{T}} ; 5, \mathrm{~T}$. otitidis DSM $8821^{\mathrm{T}}$. Data were obtained in this study. All strains were negative for acid production from xylose, D-mannitol, lactose and glycogen, hydrolysis of gelatin and activities of arylsulfatase, $\beta$ glucuronidase and $\beta$-galactosidase and positive for catalase activity. - , Negative; + , positive; $v$, variable; ND, not determined.

\begin{tabular}{|c|c|c|c|c|c|}
\hline Characteristic & 1 & 2 & 3 & 4 & 5 \\
\hline \multicolumn{6}{|c|}{ Growth in the presence of $\mathrm{NaCl}$ at: } \\
\hline $5 \%(\mathrm{w} / \mathrm{v})$ & + & - & + & + & + \\
\hline $7 \%(\mathrm{w} / \mathrm{v})$ & - & - & + & + & ND \\
\hline \multicolumn{6}{|c|}{ Growth on carbon sources (at $1.0 \% \mathrm{w} / \mathrm{v}$ ) } \\
\hline L-Rhamnose & + & - & + & + & - \\
\hline myo-Inositol & + & - & - & - & - \\
\hline D-Galactose & - & $\mathrm{V}$ & - & - & - \\
\hline D-Sorbitol & + & $\mathrm{V}$ & + & + & ND \\
\hline Maltose & + & + & + & $\mathrm{V}$ & $\mathrm{V}$ \\
\hline Sucrose & + & + & $\mathrm{V}$ & - & $\mathrm{v}$ \\
\hline Glucose & + & + & + & + & $\mathrm{v}$ \\
\hline \multicolumn{6}{|l|}{ Acid production from: } \\
\hline D-Glucose & - & - & + & + & - \\
\hline D-Ribose & - & - & + & - & - \\
\hline Maltose & - & - & + & + & - \\
\hline Sucrose & - & - & + & - & - \\
\hline Nitrate reduction & - & + & - & - & - \\
\hline \multicolumn{6}{|l|}{ Decomposition or hydrolysis of: } \\
\hline Aesculin & + & - & - & + & - \\
\hline Urea & + & - & + & - & - \\
\hline \multicolumn{6}{|l|}{ Enzyme activities } \\
\hline Alkaline phosphatase & + & - & + & + & + \\
\hline$\alpha$-Glucosidase & + & - & - & - & - \\
\hline$N$-Acetyl- $\beta$-glucosaminidase & + & - & - & - & - \\
\hline Pyrazinamidase & - & - & - & + & + \\
\hline Pyrrolidonyl arylamidase & - & - & + & - & - \\
\hline
\end{tabular}

and substituted with acetone. Finally, the samples were sputter-coated with gold in a sputter coater (Edwards Scancoat Six) and observed using a scanning electron microscope (SEM; Philips XL-30). Colony morphology of 3 - and 14-day-old cultures was studied using a stereo microscope. Cells were spherical $(0.7-1.3 \mu \mathrm{m}$ in diameter) and occurred singly, in pairs, in tetrads or in small clumps (Fig. 1). Cells were not motile and were non-sporeforming.

Phenotypic properties were determined for strain OFN $\mathrm{S} 31^{\mathrm{T}}$ and for the following type strains: Mycobacterium fallax DSM $44179^{\mathrm{T}}$, Corynebacterium amycolatum DSM $6922^{\mathrm{T}}$, Corynebacterium kroppenstedtii DSM $44385^{\mathrm{T}}$ and Turicella otitidis DSM $8821^{\mathrm{T}}$. All physiological tests were performed at $28{ }^{\circ} \mathrm{C}$. Oxidase activity was determined by monitoring the oxidation of $N, N, N^{\prime}, N^{\prime}$-tetramethyl- $p$ phenylenediamine on filter paper (Steel, 1961). Catalase production was shown by the production of bubbles after a suspension of the cells was mixed with a drop of a $3 \%$ hydrogen peroxide solution on a slide. To determine decomposition of casein, hypoxanthine, xanthine, uric acid and testosterone, the utilization of substrates as carbon sources and arylsulfatase production, we used techniques described by Boiron et al. (1993), Goodfellow \& Lechevalier (1989) and Goodfellow (1992, 1998). Testosterone is hydrolysed by OFN $\mathrm{S} 31^{\mathrm{T}}$ but casein, hypoxanthine, uric acid and xanthine are not. Other physiological results are summarized in Table 1, revealing several differences between strain OFN S31 ${ }^{\mathrm{T}}$ and the closest strains.

Antibiotic susceptibility patterns were determined by using the disc-diffusion method on Mueller-Hinton medium according to the criteria of the Comite de l'Antibiogramme de la Société Française de Microbiologie (Cavallo et al., 2008). Mueller-Hinton agar plates were inoculated with a final inoculum of approximately $10^{5}$ c.f.u. $\mathrm{ml}^{-1}$ and then antibiotic discs were applied. Diameters of zones of growth inhibition $(\mathrm{mm})$ were recorded after $72 \mathrm{~h}$ of incubation at $28{ }^{\circ} \mathrm{C}$. Strain OFN S31 ${ }^{\mathrm{T}}$ was susceptible to ampicillin

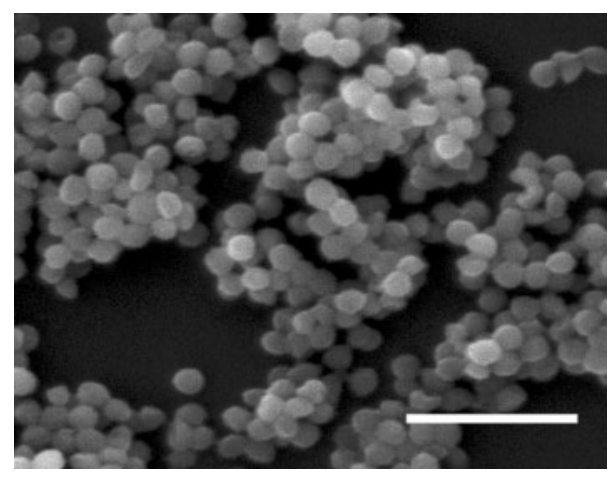

Fig. 1. Scanning electron micrograph of cells of strain OFN S31 ${ }^{\top}$. Bar, $5 \mu \mathrm{m}$. 
$(10 \mu \mathrm{g})$, amoxicillin $(25 \mu \mathrm{g})$, amoxicillin/clavulanic acid $(20 / 10 \mu \mathrm{g})$, imipenem $(10 \mu \mathrm{g})$, gentamicin $(10 \mu \mathrm{g})$, amikacin $(30 \mu \mathrm{g})$, linezolid $(30 \mu \mathrm{g})$, sulfamethoxazole/ trimethoprim $(1.25 / 23.75 \mu \mathrm{g})$, ciprofloxacin $(5 \mu \mathrm{g})$, rifampicin $(30 \mu \mathrm{g})$, cefalotin $(30 \mu \mathrm{g})$ and ticarcillin $(75 \mu \mathrm{g})$ and was resistant to trimethoprim $(5 \mu \mathrm{g})$, ceftazidime $(30 \mu \mathrm{g})$, cefamandole $(30 \mu \mathrm{g})$ and clindamycin (15 IU).

A fragment [around $1333 \mathrm{nt}$; positions 46-1400 according to the Escherichia coli numbering (Brosius et al., 1978)] of the 16S rRNA gene of strain OFN S31 ${ }^{\mathrm{T}}$ was amplified by using primers SQ1 and SQ6 as described previously by Rodríguez-Nava et al. (2004). The PCR products were purified by using a Microspin gel extraction kit (Omega; Bio-tek) and sequenced by using a Taq DyeDeoxy terminator cycle sequencing kit (Applied Biosystems) in an Applied Biosystems model 373A DNA sequencer.

The sequence determined was aligned with those of phylogenetically close reference strains obtained from the GenBank (16S rRNA) or Bioinformatic Bacterial Identification (BIBI) database (Devulder et al., 2003) by using the program CLUSTAL_X (Thompson et al., 1997). Phylogenetic and molecular evolutionary analyses were conducted using MEGA version 4 (Tamura et al., 2007) and PHYLO_WIN (Galtier et al., 1996) with three treeing algorithms, the maximum-likelihood (Felsenstein, 1981), maximum-parsimony (Kluge \& Farris, 1969) and neighbour-joining (Saitou \& Nei, 1987) methods. 16S rRNA gene sequence analysis revealed that strain OFN S31 ${ }^{\mathrm{T}}$ was distinct from all cultured members of the suborder Corynebacterineae. The closest relative of strain OFN S31 was Mycobacterium fallax ATCC $35219^{\mathrm{T}}$, with only $95.6 \%$ sequence similarity.

A sequence deposited in the GenBank database under the accession number EF564379 (Y.-N. Wang and X.-L. Wu, unpublished) as Mycobacterium sp. DQS39A1 revealed $99.8 \%$ similarity to the $16 \mathrm{~S}$ rRNA gene sequence of strain OFN S31 $1^{\mathrm{T}}$. This sequence belongs to a strain isolated from an oil-polluted soil, suggesting that strains of the species represented by strain OFN $S 31^{\mathrm{T}}$ are present in different environments.

The 16S rRNA gene sequence of strain OFN S31 ${ }^{\mathrm{T}}$ showed highest similarity to those of type strains of the suborder Corynebacterineae. The highest value of $95.6 \%$ (58 differences) was found to M. fallax ATCC $35219^{\mathrm{T}}$. The similarity values are too low to assign OFN $S 31^{\mathrm{T}}$ to any of the described taxa of the suborder Corynebacterineae. According to the phylogenetic tree shown in Fig. 2, strain OFN S31 ${ }^{\mathrm{T}}$ formed a distinct subclade close to the genus Mycobacterium, indicating that this isolate is not closely related at the 16S rRNA gene sequence level to any previously described taxa, so could represent a new genus.

The 16S rRNA gene sequence of strain OFN S31 ${ }^{\mathrm{T}}$ showed the same pattern of signature nucleotides as that published by Stackebrandt et al. (1997) for the families belonging to the suborder Corynebacterineae (Corynebacteriae, Dietziaceae, Gordoniaceae, Mycobacteriaceae, Nocardiaceae and Tsukamurellaceae) in their hierarchic classification system of the class Actinobacteria based on phylogenetic analyses of the $16 \mathrm{~S}$ rRNA gene.



Fig. 2. Phylogenetic tree derived from $16 \mathrm{~S}$ rRNA gene sequences showing the relationships between strain OFN S3 $31^{\top}$ and species belonging to the suborder Corynebacterineae. The tree was constructed by using the neighbour-joining method and was based on a comparison of 1333 nucleotides. Bootstrap values are expressed as percentages of 1000 replications. Asterisks indicate branches of the tree that were also recovered using maximumlikelihood and maximum-parsimony treeing algorithms. Bar, 0.01 substitutions per nucleotide position. 
Hypervariable regions were identified in the 16S rRNA gene sequence between strain OFN S31 $1^{\mathrm{T}}$ and the species of the genus Mycobacterium, the genus that is most closely related genotypically. These hypervariable regions covered positions $73-160,210-315,469-858$ and $1015-1340$ according to the E. coli sequence numbering (Brosius et al., 1978).

The isomer of diaminopimelic acid was analysed by TLC of whole-organism hydrolysates as described by Boiron et al. (1993). Whole-cell sugar analyses were performed following the methods described previously (Staneck \& Roberts, 1974). The acyl type of the peptidoglycan was determined by a modification of the colorimetric method of Uchida \& Aida (1977). In contrast to the original procedure, our whole-cell hydrolysate was neutralized by passing it through an ion-exchange column (Analytichem Bond Elut SCX; Varian).

Standard procedures for the analyses of fatty acids by gas chromatography were adopted with the Microbial Identification System (MIDI, Inc.) for automated GC analyses (Kroppenstedt, 1985). Mycolic acids and isoprenoid quinones were separated by HPLC (Minnikin et al., 1975; Kroppenstedt, 1982) and polar lipids were extracted and analysed by TLC using the integrated method described by Minnikin et al. (1984).

Analysis of whole-cell hydrolysates revealed meso-diaminopimelic, arabinose and galactose, consistent with an arabinogalactan polymer wall (chemotype IV) characteristic of members of the suborder Corynebacterineae. The sugars of the peptidoglycan are acetylated. This type of peptidoglycan is found only in members of three other genera of this suborder, namely Corynebacterium, Dietzia and Turicella. While phylogenetic data suggested that strain OFN S31 $1^{\mathrm{T}}$ was related to the genus Mycobacterium, the fact that the strain lacks mycolic acids indicates that it is related to C. amycolatum, C. kroppenstedtii and T. otitidis (Liebl, 2006) (Table 2).

The fatty acid pattern was composed mainly of $\mathrm{C}_{16: 0}$ $(26 \%), \mathrm{C}_{18: 1} \omega 9(20 \%)$ and $\mathrm{C}_{17: 1} \omega 9$ (13\%) (Supplementary Table S1, available in IJSEM Online). $\mathrm{C}_{18: 0}$ was present in smaller amounts for strain OFN S31 ${ }^{\mathrm{T}}$ compared with M. fallax, C. amycolatum, C. kroppenstedtii and $T$. otitidis. Another difference was the presence of tuberculostearic acid in strain OFN S31 ${ }^{\mathrm{T}}$ and its absence from $C$. amycolatum.

The menaquinone pattern revealed that MK-8 (96.7\%) was the principal menaquinone and MK-9 was present at $3.3 \%$. This feature distinguished strain OFN S31 ${ }^{\mathrm{T}}$ from M. fallax, C. amycolatum and $T$. otitidis and related it to $C$. kroppenstedtii, in which MK-8 was the major menaquinone.

The polar lipid pattern was composed of phosphatidylinositol, phosphatidylglycerol, phosphatidylethanolamine and diphosphatidylglycerol. The occurrence of the diagnostic phosphatidylethanolamine in the phospholipid

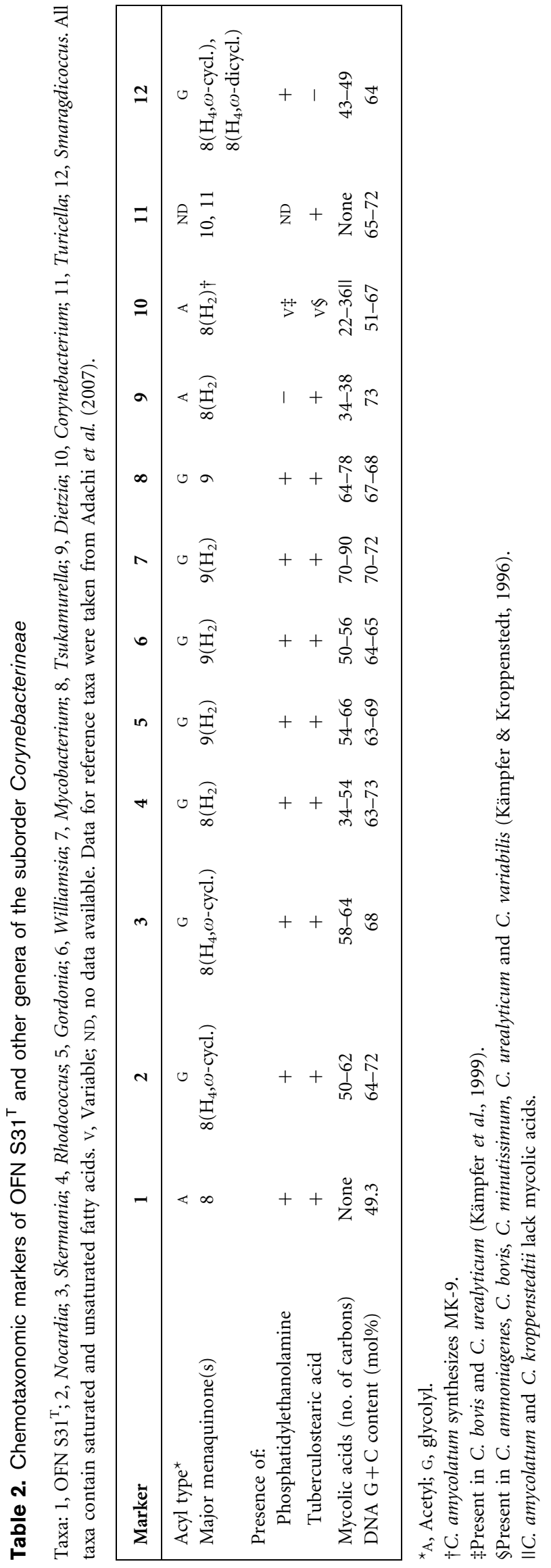


pattern of OFN S31 ${ }^{\mathrm{T}}$ separates this taxon from species of the genera Corynebacterium, Dietzia and Turicella, which lack this phospholipid.

Thus, this polyphasic taxonomic study clearly showed that isolate OFN $\mathrm{S} 31^{\mathrm{T}}$ could be distinguished readily from representatives of all phylogenetically related genera; therefore, it is concluded that this strain should be assigned to a new genus and species, for which we propose the name Hoyosella altamirensis gen. nov., sp. nov.

\section{Description of Hoyosella gen. nov.}

Hoyosella (Ho.yo.sel'la. N.L. fem. dim. n. Hoyosella named in honour of Dr Manuel Hoyos, a pioneer in research towards the protection of the Altamira Cave paintings).

Cells are non-motile, non-spore-forming and spherical and occur singly, in pairs, in tetrads or in small clumps. Gramstain-positive, aerobic, catalase-positive and oxidase-negative. Colonies are circular, smooth and cream coloured. The sugars of the murein are acetylated. Mycolic acids are absent. The fatty acid pattern is composed mainly of $\mathrm{C}_{16: 0}$, $\mathrm{C}_{18: 1} \omega 9$ and $\mathrm{C}_{17: 1} \omega 9$. The major menaquinone is MK-8. The diagnostic phospholipid phosphatidylethanolamine is found, together with phosphatidylglycerol, diphosphatidylglycerol and diphosphatidylinositol. The DNA G+C content of the type strain of the type species is $49.3 \mathrm{~mol} \%$. Phylogenetically, the genus is a member of the suborder Corynebacterineae. The type species is Hoyosella altamirensis.

\section{Description of Hoyosella altamirensis sp. nov.}

Hoyosella altamirensis [al.ta.mi.ren'sis. N.L. fem. adj. altamirensis referring to Altamira Cave (Cantabria, Spain), where the type strain was isolated].

Displays the following properties in addition to those given for the genus. Cells are $0.7-1.2 \mu \mathrm{m}$ in diameter. Colonies are about $1 \mathrm{~mm}$ in diameter. Slightly acid-alcohol-fast. Grows at $20-37{ }^{\circ} \mathrm{C}$ (optimum $28{ }^{\circ} \mathrm{C}$ ) and in the presence of up to $6 \% \mathrm{NaCl}$ (optimal growth with $2-4 \% \mathrm{NaCl}$ ). Good growth on BHI and TSA media. Phenotypic characteristics are reported in Table 1. Shows high susceptibilities to some antibiotics tested, for example penicillins, aminosides and some cephalosporins; resistance is observed to trimethoprim, ceftazidime, cefamandole and clindamycin.

The type strain, OFN S31 ${ }^{\mathrm{T}}\left(=\mathrm{CIP} 109864^{\mathrm{T}}=\mathrm{DSM} 45258^{\mathrm{T}}\right)$, was isolated from a white colony in Altamira Cave, Spain.

\section{Acknowledgements}

We thank Peter Schumann for performing the analyses of $\mathrm{G}+\mathrm{C}$ content and J. P. Flandrois for technical contributions. This work was supported by the Centre National de la Recherche Scientifique (CNRS). The authors acknowledge funding from the Spanish Ministry of Culture for the microbiological study of Altamira Cave and from the Spanish Ministry of Education and Science, project
CGL2006-07424. The facilities provided by the Museum of Altamira are acknowledged.

\section{References}

Adachi, K., Katsuta, A., Matsuda, S., Peng, X., Misawa, N., Shizuri, Y., Kroppenstedt, R. M., Yokota, A. \& Kasai, H. (2007). Smaragdicoccus niigatensis gen. nov., sp. nov., a novel member of the suborder Corynebacterineae. Int J Syst Evol Microbiol 57, 297-301.

Boiron, P., Provost, F. \& Dupont, B. (1993). Technical protocols. In Méthodes de Laboratoire pour le Diagnostic de la Nocardiose, pp. 107126. Edited by Institut Pasteur. Paris: Institut Pasteur.

Brosius, J., Palmer, M. L., Poindexter, J. K. \& Noller, H. F. (1978). Complete nucleotide sequence of a $16 \mathrm{~S}$ ribosomal RNA gene from Escherichia coli. Proc Natl Acad Sci U S A 75, 4801-4805.

Cavallo, J. D., Chardon, H., Chidiac, C., Courvalin, P., Dabernat, H., Drugeon, H., Dubreuil, L., Goldstein, F., Guery, B. \& other authors (2008). Recommandations du CASFM. Paris: Comité de l'antibiogramme de la Société Française de Microbiologie. http://www.sfm. asso.fr/

Devulder, G., Pierre, G., Baty, F. \& Flandrois, J. P. (2003). BIBI, a bioinformatics bacterial identification tool. J Clin Microbiol 41, 17851787.

Felsenstein, J. (1981). Evolutionary trees from DNA sequences: a maximum likelihood approach. J Mol Evol 17, 368-376.

Galtier, N., Gouy, M. \& Gautier, C. (1996). SeaView and PHYLO_WIN, two graphic tools for sequence alignment and molecular phylogeny. Comput Appl Biosci 12, 543-548.

Gonzalez, J. M., Portillo, M. C. \& Saiz-Jimenez, C. (2006). Metabolically active Crenarchaeota in Altamira Cave. Naturwissenschaften 93, 42-45.

Goodfellow, M. (1992). The family Nocardiaceae. In The Prokaryotes, 2nd edn, pp. 1188-1213. Edited by A. Balows, H. G. Trüper, M. Dworkin, W. Harder \& K. H. Schleifer. New York, Springer.

Goodfellow, M. (1998). The genus Nocardia Trevisan 1889. In Topley \& Wilson's Microbiology \& Microbial Infections, 9th edn, pp. 464-489. Edited by A. Balows \& B. I. Duerden. London: Edward Arnold.

Goodfellow, M. \& Lechevalier, M. P. (1989). Genus Nocardia Trevisan $1889,9^{\mathrm{AL}}$. In Bergey's Manual of Systematic Bacteriology, vol. 4, pp. 2350-2361. Edited by S. T. Williams, M. E. Sharpe \& J. G. Holt. Baltimore: Williams \& Wilkins.

Groth, I., Schumann, P., Schuetze, B., Augsten, K., Kramer, I. \& Stackebrandt, E. (1999). Beutenbergia cavernae gen. nov., sp. nov., an L-lysine-containing actinomycete isolated from a cave. Int $J$ Syst Bacteriol 49, 1733-1740.

Groth, I., Schumann, P., Schuetze, B., Augsten, K. \& Stackebrandt, E. (2002). Knoellia sinensis gen. nov., sp. nov. and Knoellia subterranea sp. nov., two novel actinobacteria isolated from a cave. Int J Syst Evol Microbiol 52, 77-84.

Jones, K. L. (1949). Fresh isolates of actinomycetes in which the presence of sporogenous aerial mycelia is a fluctuating characteristic. J Bacteriol 57, 141-145.

Jurado, V., Groth, I., Gonzalez, J. M., Laiz, L. \& Saiz-Jimenez, C. (2005a). Agromyces salentinus sp. nov. and Agromyces neolithicus sp. nov. Int J Syst Evol Microbiol 55, 153-157.

Jurado, V., Groth, I., Gonzalez, J. M., Laiz, L. \& Saiz-Jimenez, C. (2005b). Agromyces subbeticus sp. nov., isolated from a cave in southern Spain. Int J Syst Evol Microbiol 55, 1897-1901.

Jurado, V., Gonzalez, J. M., Laiz, L. \& Saiz-Jimenez, C. (2006). Aurantimonas altamirensis sp. nov., a member of the order Rhizobiales isolated from Altamira Cave. Int J Syst Evol Microbiol 56, 2583-2585. 
Jurado, V., Boiron, P., Kroppenstedt, R. M., Laurent, F., Couble, A., Laiz, L., Klenk, H.-P., Gonzalez, J. M., Saiz-Jimenez, C. \& other authors (2008). Nocardia altamirensis sp. nov., isolated from Altamira Cave, Cantabria, Spain. Int J Syst Evol Microbiol 58, 2210 2214.

Kämpfer, P. \& Kroppenstedt, R. M. (1996). Numerical analysis of fatty acid patterns of coryneform bacteria and related taxa. Can J Microbiol 42, 989-1005.

Kämpfer, P., Andersson, M. A., Rainey, F. A., Kroppenstedt, R. M. \& Salkinoja-Salonen, M. (1999). Williamsia muralis gen. nov., sp. nov., isolated from the indoor environment of a children's day care centre. Int J Syst Bacteriol 49, 681-687.

Kluge, A. G. \& Farris, J. S. (1969). Quantitative phyletics and the evolution of anurans. Syst Zool 18, 1-32.

Kroppenstedt, R. M. (1982). Separation of bacterial menaquinones by HPLC using reverse phase (RP18) and a silver loaded ion exchanger as stationary phases. J Liq Chromatogr 5, 2359-2367.

Kroppenstedt, R. M. (1985). Fatty acid and menaquinone analysis of actinomycetes and related organisms. In Chemical Methods in Bacterial Systematics (Society for Applied Bacteriology Technical Series vol. 20), pp. 173-199. Edited by M. Goodfellow \& D. E. Minnikin. New York: Academic Press.

Lee, S. D. (2006a). Amycolatopsis jejuensis sp. nov. and Amycolatopsis halotolerans sp. nov., novel actinomycetes isolated from a natural cave. Int J Syst Evol Microbiol 56, 549-553.

Lee, S. D. (2006b). Nocardia jejuensis sp. nov., a novel actinomycete isolated from a natural cave on Jeju Island, Republic of Korea. Int $J$ Syst Evol Microbiol 56, 559-562.

Lee, S. D., Kim, E. S., Roe, J. H., Kim, J., Kang, S. O. \& Hah, Y. C. (2000). Saccharothrix violacea sp. nov., isolated from a gold mine cave, and Saccharothrix albidocapillata comb. nov. Int J Syst Evol Microbiol 50, 1315-1323.

Lee, S. D., Kim, E. S., Min, K. L., Lee, W. Y., Kang, S. O. \& Hah, Y. C. (2001). Pseudonocardia kongjuensis sp. nov., isolated from a gold mine cave. Int J Syst Evol Microbiol 51, 1505-1510.

Liebl, W. (2006). Corynebacterium - nonmedical. In The Prokaryotes. A Handbook on the Biology of Bacteria, 3rd edn, vol. 3, pp. 796818. Edited by M. Dworkin, S. Falkow, E. Rosenberg, K. H. Schleifer \& E. Stackebrandt. New York: Springer.

MacFaddin, J. F. (1985). Media for Isolation-CultivationIdentification-Maintenance of Medical Bacteria, vol. 1. Baltimore: Williams \& Wilkins.
Margesin, R., Schumann, P., Spröer, C. \& Gounot, A. M. (2004). Arthrobacter psychrophenolicus sp. nov., isolated from an alpine ice cave. Int J Syst Evol Microbiol 54, 2067-2072.

Minnikin, D. E., Alshamaony, L. \& Goodfellow, M. (1975). Differentiation of Mycobacterium, Nocardia, and related taxa by thin-layer chromatographic analyses of whole-cell methanolysates. $J$ Gen Microbiol 88, 200-204.

Minnikin, D. E., O'Donnell, A. G., Goodfellow, M., Alderson, G., Athalye, M., Schaal, A. \& Parlett, J. H. (1984). An integrated procedure for the extraction of bacterial isoprenoid quinones and polar lipids. J Microbiol Methods 2, 233-241.

Rodríguez-Nava, V., Couble, A., Molinard, C., Sandoval, H., Boiron, P. \& Laurent, F. (2004). Nocardia mexicana sp. nov., a new pathogen isolated from human mycetomas. J Clin Microbiol 42, 4530-4535.

Saitou, N. \& Nei, M. (1987). The neighbor-joining method: a new method for reconstructing phylogenetic trees. Mol Biol Evol 4, 406-425.

Schabereiter-Gurtner, C., Saiz-Jimenez, C., Piñar, G., Lubitz, W. \& Rölleke, S. (2002). Altamira cave Paleolithic paintings harbor partly unknown bacterial communities. FEMS Microbiol Lett 211, 7-11.

Schumann, P., Cui, X., Stackebrandt, E., Kroppenstedt, R. M., Xu, L. \& Jiang, C. (2004). Jonesia quinghaiensis sp. nov., a new member of the suborder Micrococcineae. Int J Syst Evol Microbiol 54, 2181-2184.

Seo, J. P., Yun, Y.-W. \& Lee, S. D. (2007). Nocardia speluncae sp. nov., isolated from a cave. Int J Syst Evol Microbiol 57, 2932-2935.

Stackebrandt, E., Rainey, F. A. \& Ward-Rainey, N. L. (1997). Proposal for a new hierarchic classification system, Actinobacteria classis nov. Int J Syst Bacteriol 47, 479-491.

Staneck, J. L. \& Roberts, G. D. (1974). Simplified approach to identification of aerobic actinomycetes by thin-layer chromatography. Appl Microbiol 28, 226-231.

Steel, K. J. (1961). The oxidase reaction as a taxonomic tool. J Gen Microbiol 25, 297-306.

Tamura, K., Dudley, J., Nei, M. \& Kumar, S. (2007). MEGA 4: molecular evolutionary genetics analysis (MEGA) software version 4.0. Mol Biol Evol 24, 1596-1599.

Thompson, J. D., Gibson, T. J., Plewniak, F., Jeanmougin, F. \& Higgins, D. G. (1997). CLUSTAL_X windows interface: flexible strategies for multiple sequence alignment aided by quality analysis tools. Nucleic Acids Res 25, 4876-4882.

Uchida, K. \& Aida, K. (1977). Acyl type of bacterial cell wall: its simple identification by a colorimetric method. J Gen Appl Microbiol 23, 249-260. 